\title{
Effect of hydroalcoholic leaves extract of Datura stramonium on pathogenic
} Candida albicans

Ali Y. Salman and Mohammed K. Faraj

Department of Microbiology, College of Veterinary Medicine, Baghdad University, Iraq.

E- mail: dr.ali.yhea.salman@gmail.com

Accepted: 26/4/2015

Summary

This research aimed at studying the effect of different concentration of hydroalcoholic leaves extract of Datura stramonium concentration against pathogenic Candida albicans isolated from clinical cases of diarrhea in cows and dogs in Baghdad province. Hydroalcoholic extract of the leaves of Datura stramonium were prepared in different concentrations for In vitro and In vivo study against Candida albicans. In vitro test includes the determination of minimum inhibitory concentration $50,25,12.5,6.25,3.12$ and $1.75 \mathrm{mg} / 1 \mathrm{ml}$ ), and it was found that the minimum inhibitory concentration was $3.12 \mathrm{mg} / 1 \mathrm{ml}$. Whereas the in vivo test was performed for the determination of sensitivity test of Candida albicans in concentration of plant 10,15 and $20 \mathrm{mg} / 1 \mathrm{ml}$ which was compared with same concentration of Nystatin. The study was performed in seven groups of mice according to different concentrations. The infective dose of Candida albicans was 1X108, which was proved by histopathology changes after eight day. The result obtained from invivo study revealed that after the end of the therapeutic period that lasted for 8 days. Confirm the efficacy of Datura stramonium extract at $20 \%$ as a treatment for mice infected with Candida albicans.

Keywords: Datura stramonium, Candida albicans, Hydroalcoholic extract, White mice.

\section{Introduction}

The fungal diseases constituted a high percentage from the whole diseases in animals and humans, which are categorized in third order after the bacterial and viral diseases (1). Candidaiases is one of the fungal diseases worldwide; there are about 200 species of Candida occur saprophytically, but only Candida albicans is commonly associated with diseases in humans and animals (2 and 3). Candida albicans is found as a commensules of mucocutanous areas particularly of intestinal and genital tracts of humans and animals. Most infection are endogenous in origin, but predisposing causes such as immunosuppreion, prolong antibiotic or corticosteroids, cancer especially in human. In cattle, Candida albicans may introduce into the udder from the nosal of tubes of intramammary antibiotics (4). In dogs, Candidaiases is one of the diseases, which is regarded important to be studied, because the disease can be transmitted to human, especially the cutanous infection in dogs (5) which occurs after treatment of dogs with antibiotics orally. Most of the chemical treatment for fungi may have effect on the patient cells. Also the use of some synthetic antifungals may have an effect on the patient cells. In order to avoid the negative effects of chemicals and some of antimicrobial drugs, recent studies are directed towards the use of the medical plants, which contain active ingredients, and do not have side effects on patients. Datura stramonium is one of the medical plants which is important, the datura plant grows as woody, leafy stalk with spiny seed pods and large white or purple trumpet shaped flowers facing upwards (6), containing Scopolamine, atropine and hyoscyamine (7). It is known by many names, a few of which are Jimson weed, Davils Apple, Stinkweed and toalach (8). Scarce of studies on the use of Datura stramonium leaves extract on the pathogenic fungi which cause systemic and cutanous mycoses in animals. Therefore the aim of this research is to use the hydroalcoholic extract of Datura stramonium as antifungal in vivo and in vitro on candida albicans isolated from feces of cows and dogs.

\section{Materials and Methods}

Candida albicans, is isolated from clinical cases of diarrhea in cattle and dogs. The media used for cultivation of Candida albicans was Sabouraud dextrose agar, corn meal agar and use Rapid tm yeast plus system used for confirmation of Candida albicans. A handered 
fecal samples were taken directly from feces of cows and thirty samples from dogs suffering from diarrhea during the period from May, 2013 till the end of November, 2013. The samples were obtained from different regions in Baghdad.

The plant Datura stramonium was collected from desert of Al_Anbar province in west Iraq. This plant is naturally grown in the desert. Datura stramonium leavess were dried in shade at room temperature and ground by using blender. Two hundred fifty grams of plant powder was soaked in $1.25-1.5 \mathrm{~L}$ of 95\% methanol for 5 days at room temperature , the mixture was mixed daily for regular infusion. After 5 days the extract was filtrated by using Whitman filter paper No.1, the filtrates were dried by using a rotary avaporter at $60^{\circ} \mathrm{C}$, the dried extract was stored in sterile glass bottles at $20^{\circ} \mathrm{C}$ until use according to (9).

Different concentration of the plant were prepared $(50,25,12.5,6.25,3.12$, and 1.56 $\mathrm{mg} / 1 \mathrm{ml}$ ) at the same time. Also the same concentrations were prepared for standard antifungals Nystatin (50, 25, 12.5, 6.25, 3.12, and $1.56 \mathrm{mg} / 1 \mathrm{ml}$ ) for the in vitro study for the minimum inhibitory concentration of Methanolic extract of Datura stramonium against pathogenic $C$. albicans isolated from fecal samples in cows and dogs suffered from diarrhea. The systemic experiment used the plant alcoholic extract for treatment of diarrhea in mice 56 white Swiss BALB/C mice, the age range 5-8 weeks, divided randomly into 7 equal groups, and treated as follows. G1: (control positive) administrated Candida albicans suspension orally containing (1ml) infection dose of $1 \times 10^{8}$ live cell $/ \mathrm{ml}$. G2: This was administered with suspension of infective dose of Candida albicans of $1 \times 10^{8}$ live cell/ml and treated with DMSO. G3: administered suspension of Candida albicans $1 \times 10^{8}$ live cell $/ \mathrm{ml}$ and treated with standard antifungal Nystatine. G4: administered with suspension of Candida albicans $1 \times 10^{8}$ live cell $/ \mathrm{ml}$ and treated with dose $3 \mathrm{~g} / \mathrm{kg}$ of B.w with concentration of $100 \mathrm{mg} / \mathrm{ml}$ of datura plant extract. G5: administered with suspension of infective dose of Candida albicans $1 \times 10^{8}$ live cell $/ \mathrm{ml}$ and treated with $3 \mathrm{mg} / \mathrm{kg}$ b.w with concentration of $150 \mathrm{mg} / \mathrm{ml}$ of datura plant. G6: administered with suspension of Candida albicans $1 \times 10^{8}$ live cell $/ \mathrm{ml}$ with dose $3 \mathrm{mg} / \mathrm{kg}$ b.w with $200 \mathrm{mg} / \mathrm{ml}$ concentration of datura plant. G7: control negative Group not treated with anything.

\section{Results and Discussion}

Candida albicans was cultivated on Sabouraud dextrose agar, for 48-72 hr and appeared as small, smoth white -cream, glistening round and curved colonies at $37^{\circ} \mathrm{C}$ (Fig. 1). These result agreed with (10).

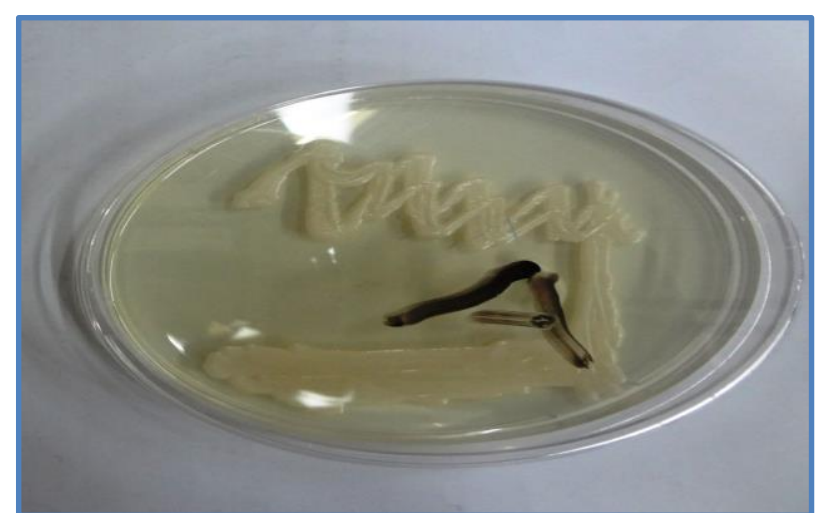

Figure, 1: Candida albicans on sabouruad dextrose agar.

The microscopical appearance of Candida albicans of tested mounts showed psedohyphae cluster of budding. In addition Candida albicans form germ tubes when grown on humen or rabbit serum for 3 hours at $37^{\circ} \mathrm{C}$, further more Candida albicans can form chlamydospores when grown on Corn meal agar, and incubated at $37^{\circ} \mathrm{C}$ for 48 hours, as appeared in the present study which agrees with (11). The main confirmed tests for identification of Candida albicans was Rapid ${ }^{\mathrm{tm}}$ yeast plus test as established by (12), which confirms the biochemical tests and API yeast. Also Chlamydospores formation is another test which is used for the identification of Candida albicans when culturing it on corn meal agar with $1 \%$ of tween- 80 and incubation at $30^{\circ} \mathrm{C}$ for 48 hours. After that small part from the Candida albicans growth was examined for the formation of chlamydospores, as a thickwall and usually produced on supporting cells at the end of the pseudomycelium. As stated by (13) illustrated in (Fig. 2). Germ tube is another diagnostic and conformation test for the pathogenic Candida albicans (14). In the present study Candida albicans isolate showed positive result as the formation of germ tubes seen as a long extending from the yeast cells like projection as in (Fig. 3). 


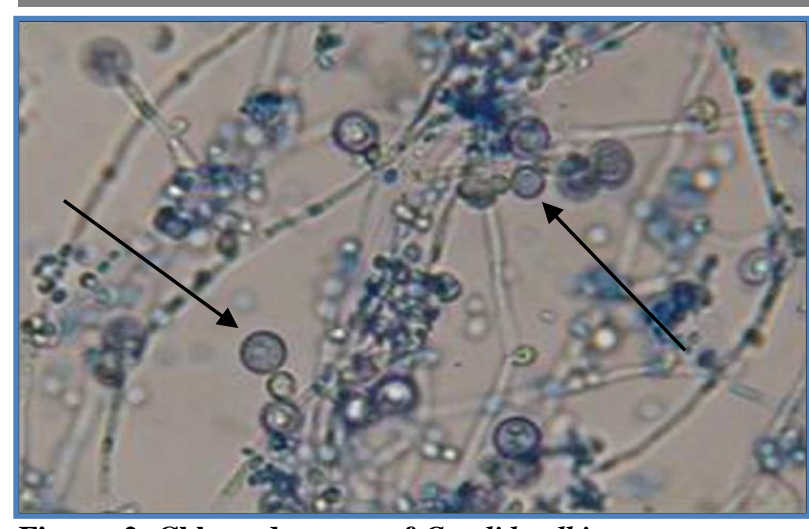

Figure, 2: Chlamydospores of Candida albicans.

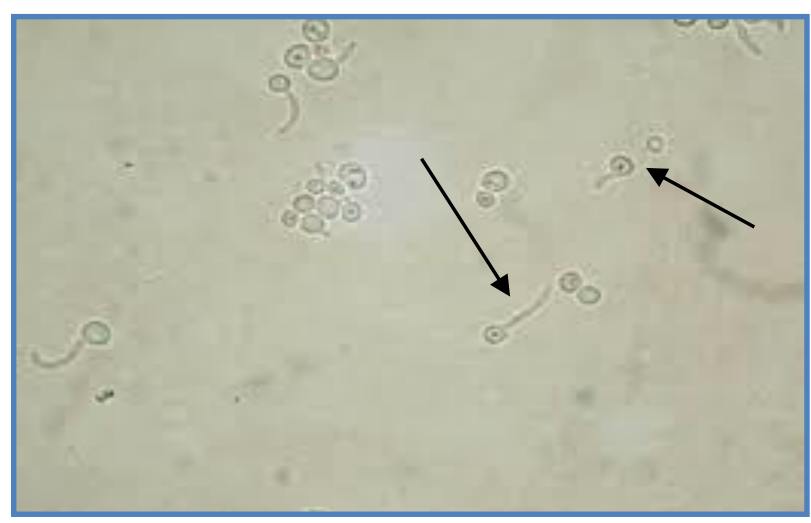

Figure, 3: Germ tube of candida albicans.

Germ tubes were formed within 2-3 hours when Candida albicans was inoculated in the serum and incubated at $37^{\circ} \mathrm{C}$ for 3 hours. The result of this study agrees with (15). Furthermore, up to $5 \%$ of the strains of Candida albicans may be germ tube negative (16). From another point, (17) found that other Candida spp may form germ tube, but rarely such as Candida tropicalis, which form psudogerm tube. The pathogenic Candida albicans isolated from clinical cases of diarrhea in cows and dogs were diagnosed confirmally by using Rapid ${ }^{\text {tm }}$ yeast plus system, and the result of this test is shown in (Fig. 4).

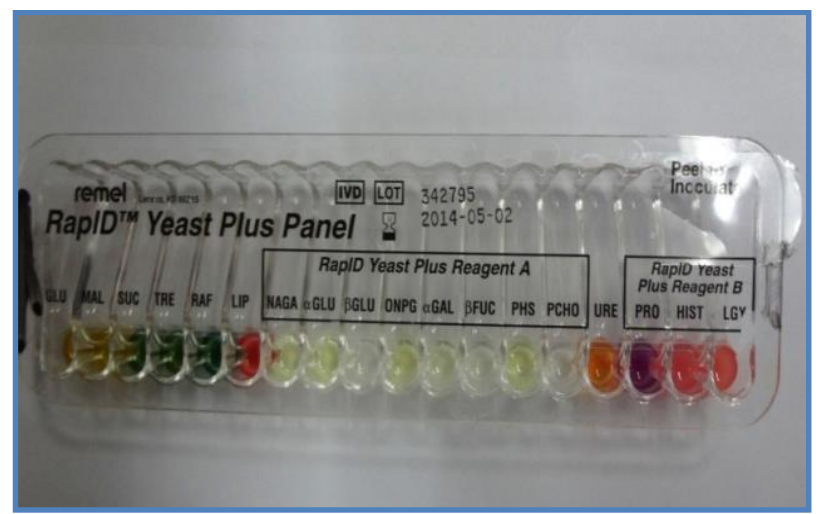

Fig. 4: Rapidtm yeast plus system show the positive reaction of Candida albicans.
The $\operatorname{Rap}^{\mathrm{tm}}$ yeast plus system is a qualitative micro method that uses conventional and chromogenic substrates for the identification of medically important yeast, yeast _like fungi and similar organisms isolated from clinical speciments (18). The isolation percentage of Candida albicans from feces of clinical cases of diarrhea were $7 \%$ from in cow, whereas the isolation percentage of Candida albicans from feces of dogs suffured from diarrhea was $23 \%$ as illustrated in (Table, 1).

Table, 1: Source of fecal samples from cows and dogs.

\begin{tabular}{|c|c|c|c|c|c|}
\hline No. & Region & $\begin{array}{l}\text { No. of } \\
\text { sample }\end{array}$ & Animals & $\begin{array}{l}\text { No. of } \\
\text { positive } \\
\text { samples }\end{array}$ & $\begin{array}{l}\text { Positive } \\
\%\end{array}$ \\
\hline 1 & $\begin{array}{l}\text { College of } \\
\text { Veterinary } \\
\text { medicine in } \\
\text { Baghdad }\end{array}$ & 15 & Cow & $\mathbf{0}$ & $\begin{array}{l}7.0 \% \\
\text { cows }\end{array}$ \\
\hline 2 & $\begin{array}{l}\text { College of } \\
\text { Agriculture in } \\
\text { Baghdad }\end{array}$ & 45 & Cow & 3 & \\
\hline 3 & $\begin{array}{l}\text { Abu-Gryab in } \\
\text { Baghdad City }\end{array}$ & 20 & Cow & 1 & \\
\hline 4 & $\begin{array}{l}\text { Aden } \\
\text { Veterinary } \\
\text { Hospital }\end{array}$ & 20 & Cow & 3 & \\
\hline 5 & $\begin{array}{l}\text { Different } \\
\text { Veterinary } \\
\text { clinical in } \\
\text { Baghdad city }\end{array}$ & 30 & Dog & 7 & $23 \%$ \\
\hline
\end{tabular}

The data obtained in this study showed that the percentages of isolation of Candida albicans from feces were $7 \%$ isolation in cows and $23 \%$ in dogs, which represented a high percent of infection with Candida albicans especially in dogs. The higher percentage of infection may related to the prolong antibiotic therapy, or the addition of antibiotics in animal feed, or due to immunosuppresion. Candida albicans is a commensal and occurs most frequently on the mucus membarane of digestive and gental tract. Candidiases involving the gastrointestin-al may result from prolong antibiotic therapy (15).

The minimum inhibitory concentration (MIC) of hydroalcoholic extract of Datura stramonium on pathogenic Candida albicans isolated from feces of infected cows were compared with MIC of standard antifungal (Nystatin), (Table, 2). 
The result at this study showed that the MIC for hydroalcoholic extract of Datura stramonium against pathogenic Candida albicans was about $3.12 \mathrm{mg} / \mathrm{ml}$, as afinal concentration, beyond this concentration 1.56 $\mathrm{mg} / \mathrm{ml}$. The pathogenic Candida albicans could grow and gave heavy growth. The result in this study revealed that the hydroalcoholic extract of Datura stramonium gave a high potency and effectivity against the pathogenic Candida albicans; this agrees with (19) who worked on the anticandidal activity of nineteenth Jordaniant plant extract. Other researchers (20) stated that ethanolic extract of Datura setramunium showed antimicrobial activities from other point (21) who worked on the effect of aqous extract of Datura stramonium found that the leaves extract of Datura stramonium at $20 \%$ concentration was more inhibitory activity against some pathologic plant fungi as Fusarium oxosporum and Aspergillus soloni.

Table, 2: Minimum inhibitory concentration (MIC) of Datura stramonium on pathogenic Candida albicans.

\begin{tabular}{|c|cc|}
\hline $\begin{array}{c}\text { Concentration } \\
\mathrm{mg} / \mathrm{ml}\end{array}$ & Plant extract & Nystatin \\
\hline 50 & N.G & N.G \\
25 & N.G & N.G \\
12.5 & N.G & N.G \\
6.25 & N.G & N.G \\
3.12 & N.G & N.G \\
1.56 & 65_70 C.F.U & 90_100 C.F.U \\
\hline
\end{tabular}

N.G: No Growth, C.F.U: Colony forming unit.

Table, 3: Sensitivity test of different concentration from leaves extract of Datura stramonium.

\begin{tabular}{|c|c|c|c|}
\hline \multirow{2}{*}{$\begin{array}{c}\text { zone of } \\
\text { inhibition } \\
(\mathrm{mm})\end{array}$} & \multicolumn{2}{|c|}{ Concentration $\mathrm{mg} / \mathrm{ml}$} & \multirow[b]{2}{*}{$100 \mathrm{mg} / \mathrm{ml}$} \\
\hline & $200 \mathrm{mg} / \mathrm{ml}$ & $150 \mathrm{mg} / \mathrm{ml}$ & \\
\hline $\begin{array}{c}\text { Datura } \\
\text { Stramonium }\end{array}$ & 12.00 & 17.00 & 26.00 \\
\hline Nystatin & 11.00 & 16.00 & 24.00 \\
\hline DMSO & 0.00 & 0.00 & 0.00 \\
\hline
\end{tabular}

The ability of hydroalcoholic leaves extract of Datura stramonium was examined and compared with the same concentration of Dim ethyl sulfooxid (DIMSO) as negative control and Nystatin as positive control. The result of hydroalcoholic leaves extract with 100, 150, $200 \mathrm{mg} / \mathrm{ml}$ showed the mean value of zone of inhibition ranging from 12.00, 17.00 and 26.00, respectively, (Table, 3 ).

Pathological finding confirmed the fungal isolation, characterized by marked suppurative reaction, inflammatory cells particularly, mononuclear cells, macrophage and Neutrophils aggregation and acute cellular degeneration. The histopathological examination of intestine after 10 days post infection without treatment, showed necrosis in intestinal villi and in liver showed microabscesses in the liver parenchym (Fig. 5 and 6).

This study used three concentrations of plant extract Datura stramonium 100, 150 and $200 \mathrm{mg} / \mathrm{ml}$ respectively. The results of Datura stramonium extract show no clear pathological changes in the organs (intestine, liver) treated for 10 days. This referred to role of this extract in killing yeast cell and repairing of tissue because this extract contains active ingredient which may act as antifungal agent. The histopathological change of intestine of mice at 10 days post infection by Candida albicans and treated with Datura stramonium extract $10 \%$ and $15 \%$ revealed infiltration of inflammatory cell mainly neutrophils and MNCs in the submucosa and the muscularis mucosa (Fig. 7 and 8).

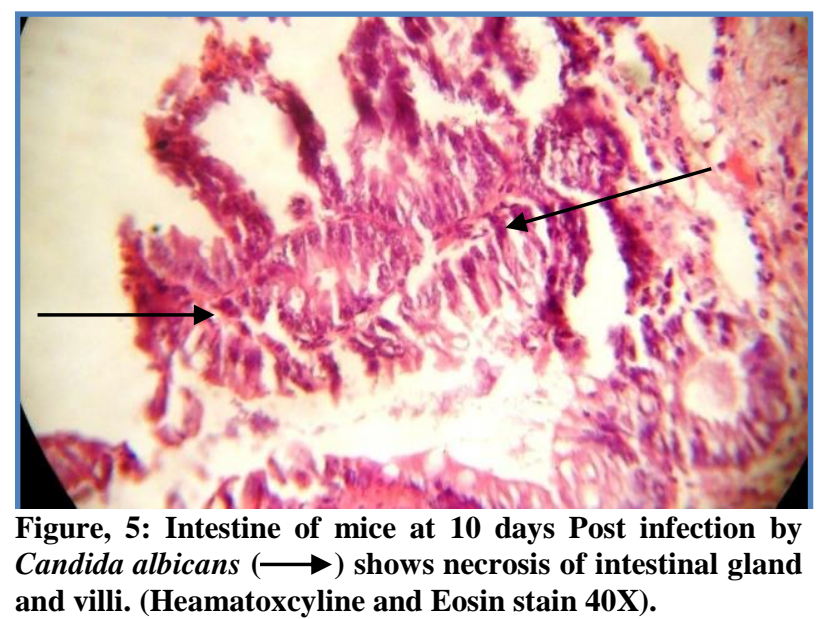

While in liver of mice at 10 days post infection by Candida albicans and treated with $10 \%$ and $15 \%$ of Datura stramonium extract for 8 days revealed aggregation of MNCs in the paranchyma with proliferation of Kupffer cells (Fig.9 and 10). 


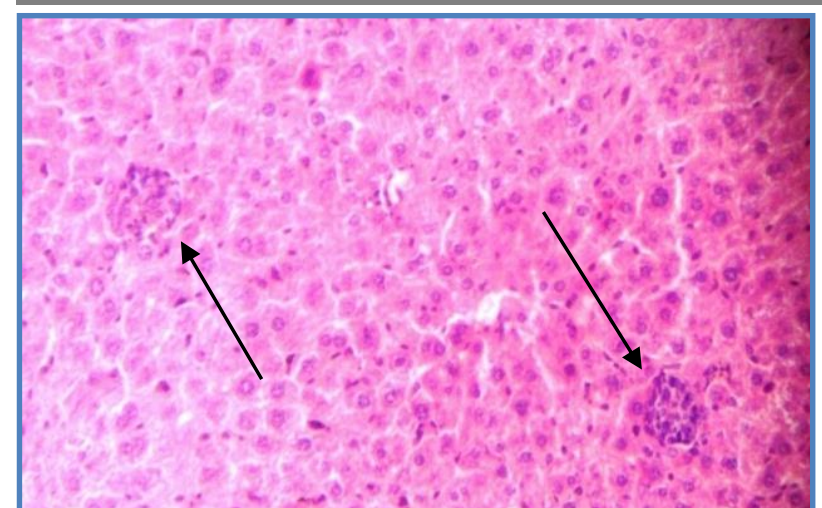

Figure, 6: Liver of mice at 10 days post infection by Candida albicans $(\longrightarrow$ ) shows microabscesses in the liver parenchyma (Heamatoxcyline and Eosin stain 40X).

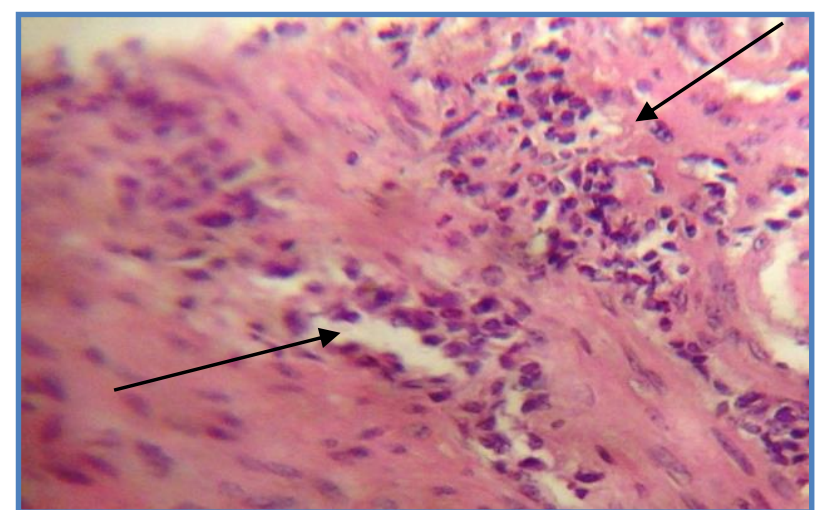

Figure, 7: Intestine of mice at 10 days post infecttion by Candida albicans and treated with Datura stramonium extract $10 \%(\longrightarrow)$ shows infiltration of inflammatory cell mainly neutrophils and MNCs in the submucosa and the muscularis mucosa (Heamatoxcyline and Eosin stain 40X).

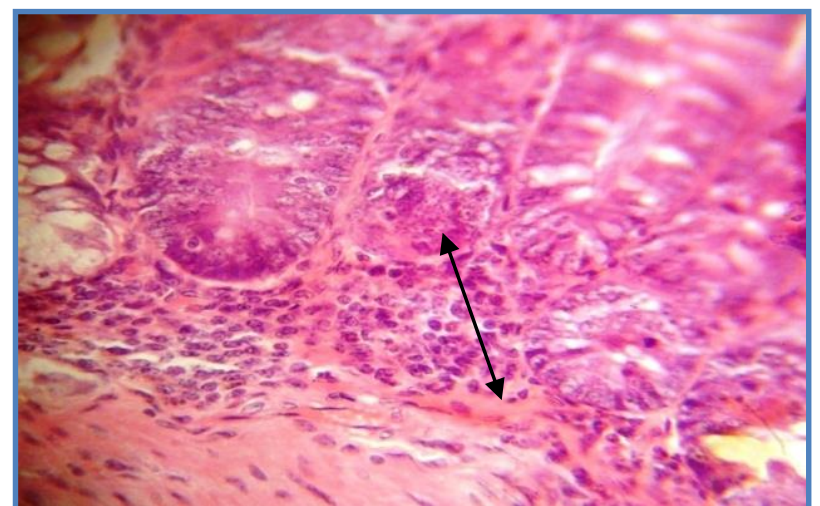

Figure, 8: Intestine of mice at 10 days post infection by Candida albicans and treated with $15 \%$ of Datura stramonium extract for 8 days $(\longleftrightarrow)$ shows mononuclear cells infiltration between mucosal gland ( $\mathrm{H}$ and Es 40X).

While histopathological change in intestine of mice at 10 days post infection by Candida albicans and treated with $20 \%$ of Datura stramonium extract after 8 days inflammation cells mainly esoinophelis and showed neutrophils in the sub epithelial layer with hyperplasia of goblet cells (Fig. 11) and pathological change in liver of mice at 10 days post infection by Candida albicans and treated with $20 \%$ of Datura stramonium extract showed Neutrophils in the liver sinasoid (Fig. 12).

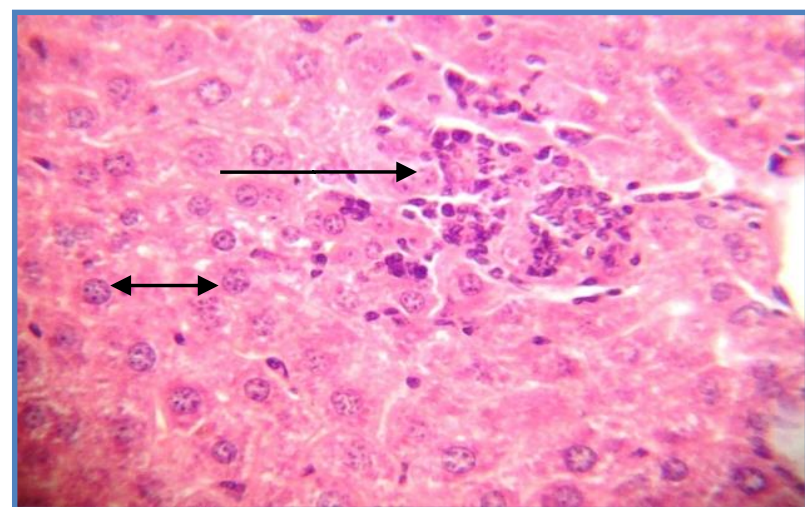

Figure, 9: Liver of mice at 10 days post infection by Candida albicans and treated with $10 \%$ of Datura stramonium extract for 8 day $(\longrightarrow$ ) shows aggregation of MNCs in the paranchyma with $(\longleftrightarrow)$ proliferation of Kupffer cells (Heamatoxcyline and Eosin stain 40X).

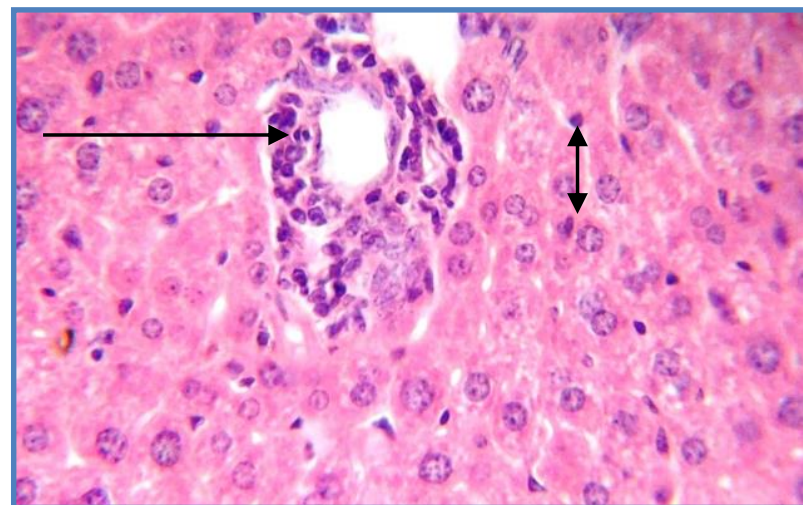

Figure, 10: Liver of mice at 10 days post infection by Candida albicans and treated with Datura stramonium extract after 8 days ( $\longrightarrow$ ) shows MNCs aggregation in the portal area with marked proliferation of Kupfer cells $(\longleftrightarrow)$ (Heamatoxcyline and Eosin stain 40X).

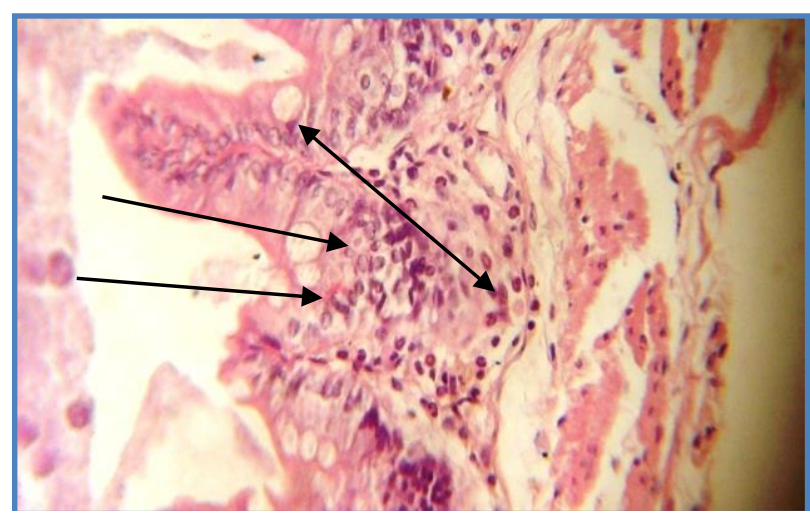

Figure, 11: Intestine of mice at 10 days post infection by Candida albicans and treated with $20 \%$ of Datura stramonium extract after 8 days $(\longrightarrow$ ) shows inflammation cells mainly esoinophelis and Neutrophils in the sub epithelial layer with hyperplasia of goblet cells $(\longleftrightarrow)$ (Heamatoxcyline and Eosin stain 40X). 


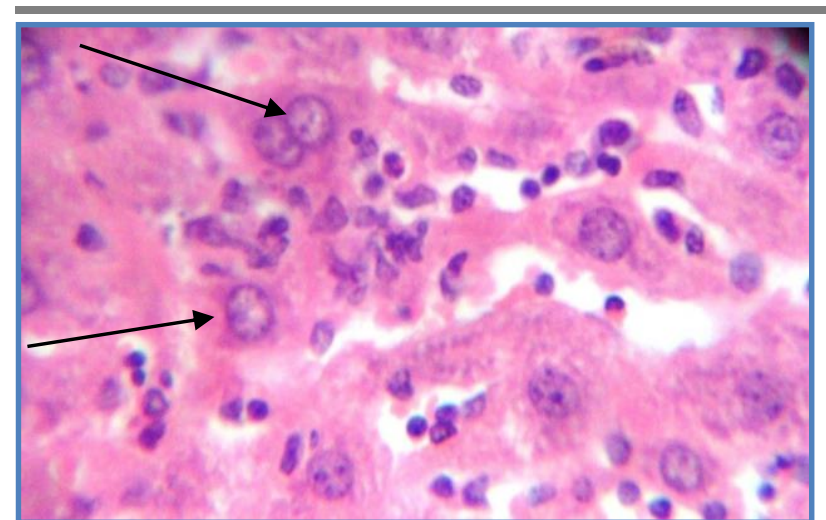

Figure, 12: Liver of mice at 10 days post infection by Candida albicans and treated with $20 \%$ of Datura stramonium extract $(\longrightarrow$ ) shows neutrophils in the liver sinasoid. (Heamatoxcyline and Eosin stain 40X).

The histopathological changes in the above sections where compared with the normal sections of intestine (Fig. 13) and liver (Fig. 14) to distinguish the effecting of Datura stramonium extract at $20 \%$ as a treatment for mice infected with Candida albicans.

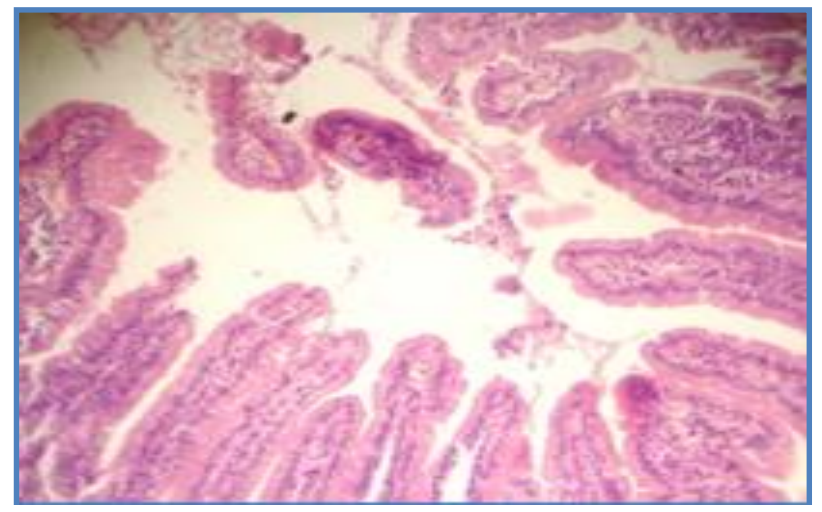

Figure, 13: Histopathological section of normal intestine of mice. (H and E 40X).

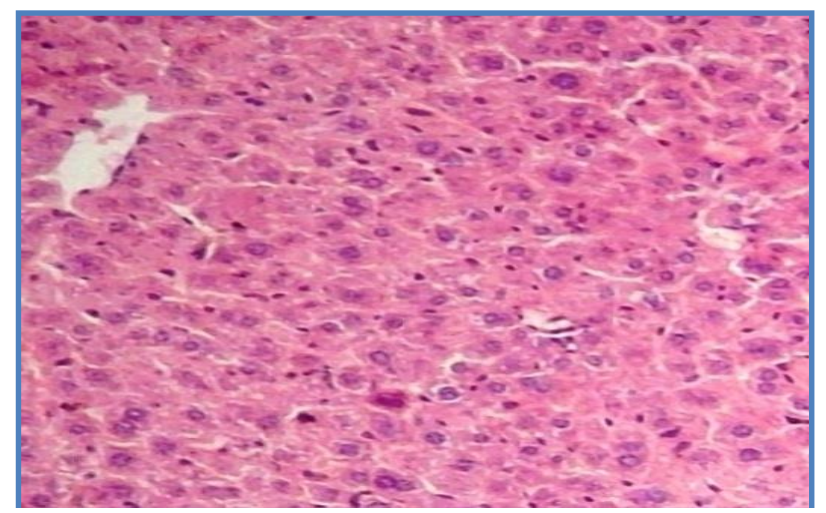

Figure, 14: Histopathological section of normal liver of mice. (H and $\mathrm{E}, 40 \mathrm{X})$.

\section{References}

1. Aniassie, E. J.; McGinnis, M. R. and Pfaller, M. A. (2003). Clinical Mycology. Churchill Livingstone, Phialadelphia. Pp: 89.

2. Manolakaki, D.; Velmahos, G.; Kourkoumpetis, T.; Chang, Y.; Alam, H. B.;
De Moya, M. M. and Mylonakis, E. (2010). Candida infection and colonization among trauma patients. Virulence, 1(5): 367-375.

3. Fugelsang, K. and Edwards Wine, C. (2010). Microbiology Second Edition, Springer Science and Business Media, New York. Pp: 3-28.

4. Krasner, R. I. (2002). Concepts of microbial disease. In the Microbial Challenge: HumanMicrobe Interactions, Washington, DC: Am. Soci. for Microb., chapter 6, Pp: 103-120.

5. Favrot, C.; Steffan, J.; Seewald, W. and Picco, F. (2010). "A prospective study on the clinical features of chronic canine atopic dermatitis and its diagnosis". Veterinary Dermatol., 21: 23-31.

6. Joshi, S. G. (2000). Medicinal Plants, Oxford and IBH Publishing Co. Pvt. Ltd., New Delhi, Pp: 370-371.

7. Eftekhar, F. Yousefzadi, M. and Tafakori, V. (2005). Antimicrobial Activity of Datura innoxia and Datura stramonium. Fitoterapia. 76: 118-120.

8. Kritikar, K. R. and Basu, B. D. (1999). Indian Meditional Plants ( $2^{\text {nd }}$ Ed.), International Book Distributors, Dehradun, India, Volume III, Pp: 1783-1787.

9. Sharma, M. C.; Sharma, S. and Kohhi, D. V. (2010). Formulation and evaluation of analgesic activity, Antiinflammatory and antanxiety activity of using plant extracts. Dig. J. Nanomaterial and Biostrudures. 5(1):147-157.

10. Alhussaini, M. S.; Noha, F. EI-Tahtawi and Ahmad, M. M. (2013). Phenotypic and molecular characterization of Candida albicans species in urin samples from renal failure patients. Sc. J. Clin. Med. 2(1): 14-25.

11. Reeta, P. R.; Ally, H.; Olga, K. and Jennifer, N. (2010). Aberrant Synthesis of Indole-3acetic acid in Saccharomyces cerevisiae Triggers Morphogenic transition, a Virulence Trait of pathogenic fungi. Genetics Society of America DOI:10.1534/genetics.109.112854.

12. Hossein, M.; Seied, H. M. and Laura R. (2011). Comparison of Enzymatic Method Rapid Yeast Plus System with RFLP-PCR for Identification of Isolated Yeast from Vulvovaginal Candidiasis. Soudian J. Basic Medical Sci., 14(5): 443-450.

13. Zavalza-stiker, A.; Ortiz-saldivar, B.; GarciaHernandez., M.; Castillocasanova, M. and Bonifaz, A. (2006). Rapid production of 
candida albicans chlamydospores in liquid mediaunder various incubation conditions. Jpn. J. Med. Mycol., 47: 231-234.

14. Koneman, E. W.; Allen, S. D.; Janda, W. M. J.; Schrecken berger, P. C. Kuleta, J. K.; and KoziK, A. (2009). Fungi pathogenic to humans: Molecular basis of virulence of Candida albicans, Cryptococcus Neoformans and Aspergillus Fumigatus. Acta. Biochim. Pol., 56: 211-224.

15. Carter, G. R. and Darla. J. W. (2004). Essentials of veterinary Bacteriology and Mycology 6th edition Lowa state press. Blackwell publishing company. Pp: 105.

16. Salkin, I. F.; Land, G. A.; Hurd, NM. J.; Goldson, P. R. and McGinnis, M. R. (1987). Evaluation of the yeast Ident and uni-yeast identification systems. J. Clin. Microbiol., 25: 624-627.

17. Baron, E. J. and Finegold, S. M. (1990). Formulas and preparation of culture media and reagent. Bailey and Scotts Diagnostic
Microbiology, $8^{\text {th }}$ ed. The C.V. Mosby Company, St. Louis, MO. Pp:60.

18. Tasan, T. K.; Michael, R. J.; Michael, R. M. and Peter, C. A. (1996). Ability of Rap ID Yeast plus System to Identify 304 clinically significal yeast within 5 hours. J. Clin. Microbiol., 34: 1067-1071.

19. Darwish, R. and Aburjia, T. (2010). Effect of Ethanomedicinal Plant Used in folkloric Medicine as Antibiotic resistant inhibitor on Escherichia coli. BMC. Complementary and Alternative Medicine, 10(9): 1-8.

20. Aqib S. and Mohib S. (2014). Phytochemstry, pharmacological and traditional uses of Datura Stramonium L. review. J. Pharmacognosy and Phytochemistry, 2(5): 123-125.

21. Gachande, B. D. and Khillare, E. M. (2013). In-vitro Evaluation of Datura species for potential Antimicrobial activity. Bioscience Discovery, 4(1): 78-81.

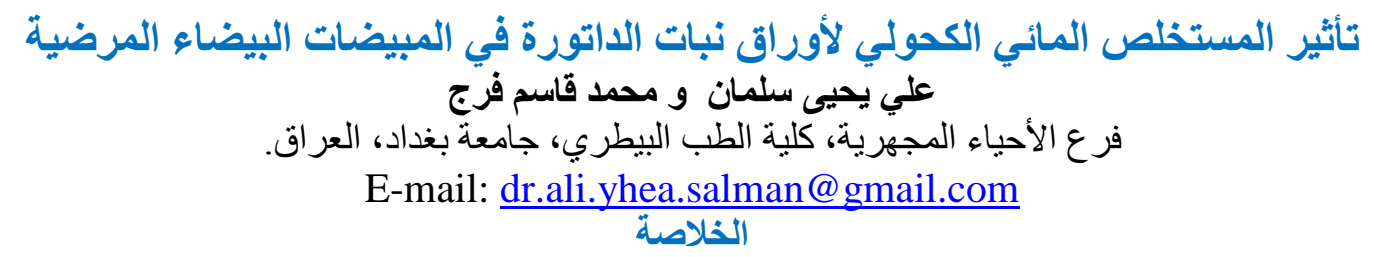

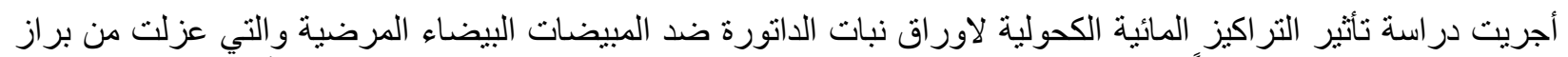

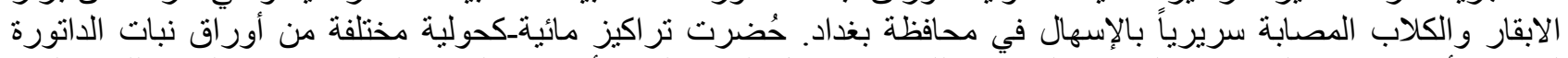

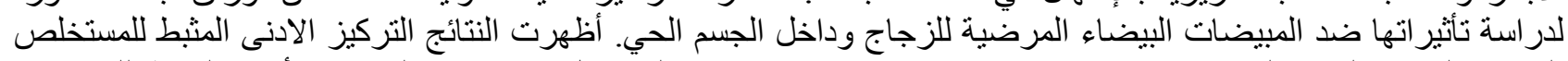

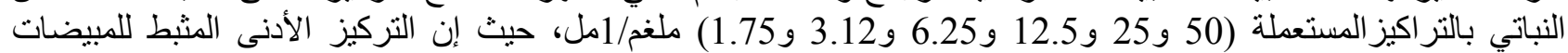

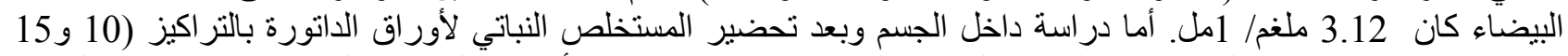

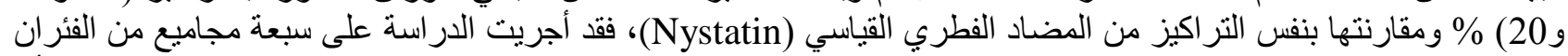

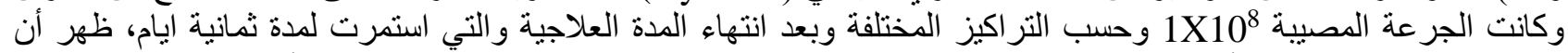

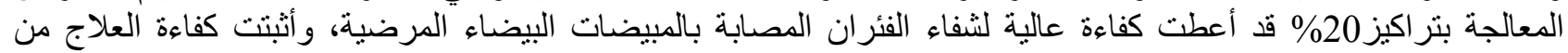

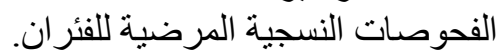
الكلمات المفتاحية: نبات الداتورة، المبيضات البيضاء البيضاء المرضية، التراكيز المائية الكحولية، الفئران البيضاء. 